\title{
Students' Attribution in Online Learning at English Department Students of Stkip Abdi Pendidikan Payakumbuh
}

\author{
Dra. Desfi Yenti, M.Pd ${ }^{1}$, Ifna Nifriza, M.Pd ${ }^{2}$ \\ ${ }^{1}$ English lecturer of STKIP Yayasan Abdi Pendidikan, desfiyenti.yen@gmail.com \\ ${ }^{2}$ English lecturer of STKIP Yayasan Abdi Pendidikan, ifnanifriza87@gmail.com \\ (c) (i) (2) \\ (C)2021 by the authors. Submitted for possible open access publication under the terms and conditions of the Creative Commons \\ Attribution-ShareAlike 4.0 International License-(CC-BY-SA) (https://creativecommons.org/licenses/by-sa/4.0/) \\ DOI : https://10.30983/mj.v1i1.5125

\begin{tabular}{l|l|l} 
Submission: October 21, 2021 & Revised: December 02, 2021 & Published: December 31, 2021
\end{tabular}

\begin{abstract}
Abstrak
Pembelajaran daring dapat dianggap sebagai salah satu jalan alternative system pendidikan dimana proses pembelajaran dilakukan dengan menggunakan ICT dengan bantuan jaringan internet. Namun dalam pelaksanaannya tidak mudab bagi sebagian mahasiswa atau sulit dan dapat diatasi bagi sebagian yang lain atau mudah. Atribusi adalab bagaimana seseorang mengakui penyebab dari kesuksesan atau kegagalannya dalam kebidupan. Penelitian ini bertujuan untuk. mengidentifikasi atribusi mahasiswa bahasa Inggris dalam pembelajaran daring menggunakan metode quantitatif. Angket digunakan sebagai instrument pengumpul data yang terdiri dari 32 butir yang disebar kepada mahasiwa responden. Kemudian data tersebut dianalisis secara quantitatif melalui penghitungan statistic dengan menggunakan rumus tertentu. Temuan menunjukkan mahasiswa menganggap kesuksesan mereka ataupun kegagalan meraka dalam pembelajaran daring umumnya disebabkan oleh usaha mereka sendiri sebagai faktor internal. Kesulitan atas tugas yang diberikan menjadi faktor eksternal terkecil yang menjadi penyebab kesuksesan dan kegagagalan pembelajaran daring. Hal ini berimplikasi bahwa kesuksesan dan kegagalan disebabkan oleh factor nternal yakni kurangnya usaha. Dengan demikian perlu solusi dengan peningkatan mutu pmebelajaran bahasa Inggris terutama bagaimana membangkitkan motivasi dan kesadaran belajar mandiri mahasiswa.
\end{abstract}

Kata Kunci: Attribusi, pembelajaran daring, factor internal, ekternal, kesuksesan, kegagalan

\begin{abstract}
Online learning can be seen as an alternative to the education system in which teaching and learning process is conducted by utilizing Information and Communication Technology (ICT) through integrating an internet connection. However, there are some students who carry out online learning successfully while some are difficult to carry out online learning or failure. Attribution is how people explain the causes of their own successes and failures. This study aims to identify students' attribution in online learning at English university students. This research used a quantitative design. The questionnaire was used as the instrument of research which consists of 32 items distributed to respondents. Then, the data were analyzed quantitatively through statistical account using certain formula. The results showed that students perceive their success and failure in online learning was mostly caused by their efforts as internal factor. Task difficulty as external factor was the least causes of students 'success and failure in online learning. This finding implies that students perceive their success and failure in online learning were caused by internal factor that is lacking of effort. Therefore, the solutions are needed to improve the quality of English online learning process especially to maintain students' motivation and effort to be autonomous.
\end{abstract}

Keywords: Attribution, Online Learning, Learning English, success, failure

\section{Introduction}

The Covid-19 pandemic has affected all sectors in Indonesia. To prevent its outbreak, most of educational institutions have to adapt the new policy in teaching learning process. Then, to break the chain of the spread of Covid-19, the government through the Ministry of Education and Culture has issued a circular instructing people to do remote learning and study from their homes (Learning from Home (LFH). Learning from home is implemented with a distance learning system. Chun, Kern, and Smith (2016) summarizes that distance learning is an education 
system in which learners are separated from the educator and the learning process uses various resources through Information and Communication Technology.

In the implementation, the distance learning system is applied through online learning. Online learning is a learning system without directly face to face between teacher and students (Allen \& Seaman, 2007). The online learning requires an internet network. The teacher and students carry out learning together, at the same time, but in different places. Bentley, Selassie, and Shegunshi (2012) define that online learning is a teaching and learning system that incorporates an internet connection. Students might use media technology to carry out the learning process indirectly through online learning. They can receive material and explanations from their professor, submit their work, and even engage in virtual chats with their instructor and peers.

Because online learning becomes a must in every school and college, adaptation needs to be conducted as a response to the changing learning system from the conventional one to online learning (Mamluah \& Maulidi, 2021). Facts shows that in this adaptation of online learning, not all students can achieve the optimal result of their academic achievement. They still found some problems in online learning such as weak mastery of IT, limited supporting facilities, internet network access (Efriana, 2021). Then, the survey research conducted by Asri \& Fauzi (2021) also found several barriers in online learning ranging from large quota, multiple tasks, limited IT mastery, unstable networks and so on.

To run the online learning process successfully, students must meet several requirements such as the capability to do online learning, the effort to maximize the learning process, to be accustomed with online task and other unpredictable factors. All of these factors will affect the students' success and failure in online learning. Thus, there is a need to interpret the causes of their success and failure in online learning.

The way how human perceive their success and failure called as attribution theory. Attribution theory focuses on how people explain the causes of their own successes and failures (Weiner, 1985). Weiner believed that four main factors impact attributions which he placed within these dimensions, namely: ability, effort, task difficulty and luck. Two of those four factors are internal to learner: ability and effort and two are attributable to external circumstances outside the learner : task difficulty and luck. Internal is when students define their online learning success and failure is caused by themselves. External, on the other hand, occurs when students attribute their success or failure to factors outside of their control.

Attribution is a theory that explains how humans explain their own actions, as well as the consequences of that activity. The factors that people attach to perceived triumphs and failures in their life. Richards and Schmidt (2002) states that attribution plays a substantial effect in their subsequent level of motivation and conduct. Attribution theory demands someone to understand and explain the reasons and factors causing an event happening to him in the past, since it possibly help them attain better strategy and expectation to solve the problem with better output (Gray, 2005; Lei, 2009; Mali, 2015; Weiner, 1985).

People are more likely to wonder why others or themselves behave the way they do or how they explain the causes (attribute) of their success and failure. Several researches had been conducted in relation to students' attribution in learning English.

Bouchaib, B., Ahmadou, B., \& Abdelkader, S. (2018) had done the research to high school students in Marocco and found that students attribute their success mostly to external factor. 
Mahfudillah (2016) conducted the research to college students in EFL speaking class in Bandung. The finding of his research showed that the major students' attribution was lack of self-confident.

Moreover, Sahinkarakas (2015) had done the research about Young Students' Success and Failure Attributions in Language Learning. He found that the factors that affect young students' successes and failures in learning a foreign language with specific focus on the role of perceived causal attributions were examined. The content of self-assessment papers of 52 young learners studying English was analyzed to investigate the students' success and failure attributions. It was found that both attributions were linked mostly to internal and unstable factors, with listening to the teacher and doing homework being the most significant. The results highlight the importance of language teachers' awareness of their students' attributions.

However, there is rarely research had done in terms of attribution in online learning. Therefore, this research is carried out to identify the students' attribution in online learning. This research focuses on the actual issues about the causality of college students' success and failure in online learning.

\section{Method}

This research was descriptive quantitative. The respondents of this research were the students of English Department of STKIP Abdi Pendidikan Payakumbuh. They were selected by using purposive sampling. Because of the number of students each class was not equal, $50 \%$ students was chosen from each class. There were 25 students taken as respondents. Close endedquestionnaire was used to collect the data. It consists of 32 items. The questionnaire was constructed based on Weiner's Theory. There are two indicators, internal and external. Each indicator had two sub indicators with 8 items from each.

Table 1 The Indicators of Students' Attribution in Online Learning

\begin{tabular}{|cccc|}
\hline NO. & INDICATOR & $\begin{array}{c}\text { SUB- } \\
\text { INDICATOR }\end{array}$ & ITEM \\
\hline 1. & Internal & Ability & $1-8$ \\
\cline { 3 - 4 } & & Effort & $9-16$ \\
\hline 2. & External & Luck & $17-24$ \\
\cline { 3 - 4 } & & Task Difficulty & $25-32$ \\
\hline
\end{tabular}

There are two indicators in attribution; they are internal factor and external factors. Internal factor had two sub indicators: ability and effort, while external factor consists sub indicator luck and task difficulty. Eight items for each sub indicator consists of four statements for the causes of students' success and four statements for the causes of students' failure in online learning. Students were asked to choose Likert -scale items expressed in terms of degree of agreement: Strongly Agree (SA), Agree (A), Undecided (U), Disagree (D), and Strongly Disagree (SD). The students' choice was given the score, 5 for Strongly Agree (SA), 4 for Agree (A), 3 for Undecided (U), 2 for Disagree (D), and 1 for Strongly Disagree (SD). Students' responses from the questionnaire were counted quantitatively to find out how students perceive the causes of their success and failure in online learning. 


\section{Finding and Discussion}

After analyzing the data, the result can be shown in the following table:

Table 2. The Result of Students' Attribution in Online Learning

\begin{tabular}{|c|c|c|c|c|}
\hline NO. & INDICATOR & $\begin{array}{c}\text { SUB- } \\
\text { INDICATOR }\end{array}$ & ITEM & $\begin{array}{l}\text { TOTAL } \\
\text { SCORE }\end{array}$ \\
\hline \multirow[t]{3}{*}{1.} & Internal & Ability & $1-8$ & 638 \\
\hline & & Effort & $9-16$ & 721 \\
\hline & & \multicolumn{2}{|c|}{ Total } & 1359 \\
\hline \multirow[t]{3}{*}{2.} & External & Luck & $17-24$ & 633 \\
\hline & & Task Difficulty & $25-32$ & 613 \\
\hline & & \multicolumn{2}{|c|}{ Total } & 1246 \\
\hline
\end{tabular}

From the table above, it can be seen that students attribution was divided into two indicators; internal and external attribution. The total score of internal attribution was higher than external attribution. It shows that the students success and failure in online learning mostly caused by internal attribution that consists of ability and effort. In internal attribution, effort was not only higher than ability but also the highest among four indicators of attribution which means most of students think that their success and failure in online learning is caused by their effort followed by ability. Moreover, in external attribution, students perceive their success and failure in online learning cause of luck and task difficulty. From four indicators of attribution, task difficulty got the lowest score.

The researchers classified each item of questionnaire based on sub indicator from indicator of attribution; they are internal attribution with ability and effort, external attribution with luck and task difficulty. Then, the students' responses of questionnaire were classified of each sub indicator as follow:

\section{Internal Attribution}

There are two sub indicators in internal attribution, they are ability and effort. The result of the data analysis presented in the following table:

Table 2. Students' Score in Internal Attribution

\begin{tabular}{|lll|}
\hline NO & Sub Indicator & Total score \\
\hline 1. & Ability & 638 \\
\hline 2. & Effort & 721 \\
\hline
\end{tabular}

From the table above, it can be seen that in the internal attribution, from $\mathbf{s b}$ indicators ability got score (638). Meanwhile, from the sub indicators effort got score (721). In Table 2 , it can be seen that effort got higher score than ability. This result shows that students' attribution in online learning is dominantly caused by effort as internal attribution. The result of the data analysis can be seen as follow: 


\section{a. Ability}

The data of students' attribution in online learning in sub indicator ability had 8 items. The total score can be seen in table 3 .

Table 3.Students' Internal Attribution in Sub indicator Ability.

\begin{tabular}{|llc|}
\hline No. & Items & Total score \\
\hline 1. & Item 1 & 99 \\
\hline 2. & Item 2 & 89 \\
\hline 3. & Item 3 & 97 \\
\hline 4. & Item 4 & 100 \\
\hline 5. & Item 5 & 50 \\
\hline 6. & Item 6 & 70 \\
\hline 7. & Item 7 & 63 \\
\hline 8. & Item 8 & 70 \\
\hline & Total & 638 \\
\hline
\end{tabular}

The items in the above table related to students internal attribution with sub indicator ability. Four statements are for the causes of students' success and four statements for the causes of failure. The sub indicator causes of students success consisted with statements such as "I got good mark in online learning because: "I master the computer as well, "I like online material", "I can operate the application used in online learning", "I can follow the technology development".

The statements given by the students showed how students prefer to make attribution on their success in online learning mainly came from their internal factor, their own ability.

Then, the causes of students' failure in online learning consisted with statements such as" I got low mark in online learning because: "I have low IQ", "T have lack ability in online learning ", I cannot master the application used in online learning", I have lack attention toward the material"

The statement from the students also made attribution as their own responsibility, for having lack of ability.

\section{b. Effort}

The data of students 'internal attribution in sub indicator effort had 8 items. The total score can be seen in table 4 .

Table 4 Students'Attribution in Online Learning in Sub Indicator Effort.

\begin{tabular}{|lcc|}
\hline No. & Items & Total score \\
\hline 9. & Item 1 & 115 \\
\hline 10. & Item 2 & 112 \\
\hline 11. & Item 3 & 118 \\
\hline 12. & Item 4 & 113 \\
\hline 13. & Item 5 & 56 \\
\hline 14. & Item 6 & 67 \\
\hline 15. & Item 7 & 68 \\
\hline 16. & Item 8 & 72 \\
\hline & Total & 721 \\
\hline
\end{tabular}


The items in the table above showed the score of students 'attribution based on effort. Four statements (item 9-12) ask the students about the causes of their success in online learning such as" I got good mark in online learning because "I do some efforts to add my knowledge in operating the computer," I finished the online learning task on time", "I am present in online learning, "I motivate myself to get a good mark in online learning".

The score on the table showed that the students attribute their success major in their effort. The higher score can be interpreted that students had tried some efforts in order they could achieve good mark in online learning.

Meanwhile, the causes of students' failure include statements (item 13-16) such as" I got low mark in online learning because: "I don't do any effort to add my knowledge about online learning", I have lack preparation in online learning", I rarely read the material in online learning, "I rarely ask friends or lecturers if I don't understand the online learning".

The score got from the causes of the failure were lowest than the causes of the success. It can be said that students perceive their failure in online learning was not major cause of their lack of effort.

\section{External Attribution}

The result of the data analysis from external attribution can be seen in the following table:

Table 5 Students' Score of External Attribution

\begin{tabular}{|ccc|}
\hline NO & Sub Indicator & Total score \\
\hline 1. & Luck & 633 \\
\hline 2. & Task Difficulty & 613 \\
\hline
\end{tabular}

From the table above, it can be seen that in the external attribution, sub indicator luck got the score (633). It is higher than the second sub-indicator task difficulty with score (613). This result shows that in external attributions most students perceive their success and failure mostly caused by in luck. The details can be seen as follow:

\section{a. Luck}

The data of students' attribution in online learning in sub indicator luck had 8 items. The total scores can be seen in table 6 .

Table 6 Students' Attribution in Online Learning in Sub Indicator Luck.

\begin{tabular}{|ccc|}
\hline No. & Items & Total score \\
\hline 17. & Item 1 & 96 \\
\hline 18. & Item 2 & 93 \\
\hline 19. & Item 3 & 90 \\
\hline 20. & Item 4 & 95 \\
\hline 21. & Item 5 & 71 \\
\hline 22. & Item 6 & 70 \\
\hline 23. & Item 7 & 56 \\
\hline 24. & Item 8 & 62 \\
\hline & Total & 633 \\
\hline
\end{tabular}

The items in table above related to student attribution in sub indicator luck. Four statements (17-20) ask the students about their causes of success in online learning in sub 
indicator luck such as "I got good mark in online learning because "I have good internet connection, "I stay in the good internet service area", "I read the material in online learning", I have a good lecturer in online learning".

Luck as unpredictable factor in attribution theory was also perceived as one of the causes of students' success in online learning. Some students chose these statements as their reason why they were succeed in online learning.

Meanwhile, the causes of their failures were asked with four statements such as :"I got low mark in online learning because: "the lecturer didn't teach well in online learning", I stay in the bad internet connection area. "I don't have support system in online learning." I don't have helpful friend in online learning".

The students' responses about the cause of their failure also perceive by unlucky things. They viewed their failure was not caused by themselves but outside one.

\section{b. Task Difficulty}

External attribution includes task difficulty, where task difficulty refers to the degree or level of task given to the students. The total scores can be seen in table 7 .

\section{Table 7 Students' Attribution in Online Learning in Sub Indicator}

Task Difficulty.

\begin{tabular}{|ccc|}
\hline No. & Items & Total score \\
\hline 25 & Item 1 & 83 \\
\hline 26. & Item 2 & 86 \\
\hline 27. & Item 3 & 77 \\
\hline 28. & Item 4 & 99 \\
\hline 29. & Item 5 & 54 \\
\hline 30. & Item 6 & 75 \\
\hline 31. & Item 7 & 75 \\
\hline 32. & Item 8 & 64 \\
\hline & total & 613 \\
\hline
\end{tabular}

Four statements ask the students' response about the causes of their success in online learning in sub indicator task difficulty such as

". I got good mark in online learning because: "the task given in online learning is not difficult. "I understand the material given easily. "the task given is not difficult. "the task given is suitable with the material that has taught by the lecturer

From the students' response, it can be seen that the difficult task also one of the factor become the causes of the students' success in online learning.

Meanwhile, the causes of the students failure in online learning in sub indicator task difficulty were responded by students as followed: "I got good mark in online learning because : "Ii difficult to use the application in online learning" I don't understand the task given by the lecturer in online learning. " the online learning's task is difficult for me". "the task given in online learning was different from the explained material.

The score of students' response on these indicators was the lowest one. It means that not many students perceive that the task difficulty was the cause of their success and failure.

Based on the result from the questionnaire, it shows that the score of internal attribution was higher than external attribution with score (1359). It happens because 
their successes and failures occur in student's observed behavior and are caused by internal factors. Like attitudes, certain traits, or other internal aspects. For example in online learning, if students have the ability and effort in online learning, they will get good grades in online learning. Furthermore, students may refer to causes that are associated with the person's innate characteristics. Internal attribution occurs when students explain success or failure in terms of themselves. These findings are also consistent with the study done by Hsieh (2004) who reported that successful learners make more internal, personal, and stable attributions. As well, Abida (2004) reported that good students made internal attributions while poor learners attributed their achievements to external factors like task difficulty. A research done by Genc (2016) investigated Turkish tertiary level EFL learners' attributions. He reported that EFL learners were more inclined to attribute success to internal factors while blaming external reasons for their failure. Interestingly, the findings are also consistent with those obtained in Bzioui's study. Bzioui reported that Moroccan successful students attribute success primarily to their high motivation/interest (an internal attribution). A possible interpretation of this finding is that perceived successful learners recognize that they can continue to achieve high as long as they put ability and effort into online learning.

The findings obtained in this study also showed that external attribution got lowest score than internal attribution. It happens because inexternal attribution, students tend to think that the cause of their success and failure was caused by external of a person, like social behavior, it is observed due to the circumstances or environment outside the person concerned. For example: if students get low grades in online learning, then the reason could be because there is a problem with the environment, maybe because of bad internet connection, living in an area that far away from internet connection, difficulty of the task, the teacher who is not interesting, or the situations that the students are not supportive for online learning. Thus, they could not run online learning well. Different studies have more or less come to the same conclusion. Noteworthy also is the fact that the findings are also theoretically supported, though only partially so. Like what Bouchaib, Ahmadou, Abdelkader (2018) found that students tend to perceive the causes of their success and failure from their own not outside them.

From four factors of attribution, the effort got the highest score (721). The researcher assumed that students had the perception that to do some efforts in online learning such as; add the knowledge about how to run a computer, finishedtheir task right on time, motivated themselves to get a high mark on their assignments could increase their achievement in online learning. The opinion is supported by Mkumbo and Amani (2012), effort is the most important factor in which learners can exercise a great deal of control. It means that effort relates to how much work those students to do achieve something.

The second highest from the indicators was ability with the score (638). Some students think that their success and failure in online learning was caused by their ability. As the students had knowledge about online learning, theywere interested in doing online learning, they also think that online learning is not difficult because they have capability on it. Those are the reason why students can successfully in doing online learning. As Brown ((2005) states that the key of learning success is students' believe. If the students believe that their ability can determine their success and failure, they can make any effort to attain the target.

Next, the students also perceive their success and failure caused by external factor. Luck got score (633). Based on the result it can be seen that luck as an external factor is chosen as the causes of their success and failure in online learning. There are some unpredictable reason why students success or failure such as : students had a bad internet 
connection or do not have supported facilities to run the students in online learning or their lecturer do not have sufficient competency in teaching through online. This result is similar to the research done by Widayanti \& Suarnajaya (2021) who found that unsupportive situation make students lose their focus and believe on online learning.

Finally, task difficulty got the lowest score from four indicators of attribution (613). Learning through online raises a number of problems especially for English Department students include the level of task difficulty. In relation to attribution, this factor was chosen as one of the causes of students' success and failure in online learning but got the lowest score. This result is different to what Ferri et al (2020) and Khalil (2021) found that online learning provide many tasks to deal with deadline which pressure students to finish the task and make them burn out. That implies that English department students were accustomed with online task since most lecturers have utilized the ICT in teaching before the Covid-19 pandemic.

\section{Conclusion}

From the discussion above, it can be summed up that the students perceive their success and failure in online learning both internally and externally. They perceive that their success and failure can be caused by the factors come from themselves and out of the students. It is also shown that students attribute their success and failure mostly caused by the internal factors.

The implementation of online learning as the solution of covid-19 pandemic makes the change of students believe towards the causes their success and failure in online learning. When students perceive something as a hindrance or the causes of their success and failure, they will do some effort in online learning to remove the hindrance or causes. Also, it is always meaningful to examine students' views, beliefs, attitudes, preferences and perceived causes of success and failure as the findings can provide insight into how to go about online learning and make it more successful, thus the importance of such studies. The study of this nature can help improve online teaching learning process in such a way as to support and enhance online learning to English department students. To sum up, further research using different data collection methods and targeting different learner groups is desirable so that deeper insights are provided into causal attributions which are to be acted on with the purpose of improving online learning process.

\section{References}

Adiba, F. (2004). Study of attributions of low achievers and high achievers about the perceived causes of their success and failure. Ph.D. dissertation, University of Arid Agriculture, Rawalpindi.

Arends, Richard I. (2012). Learning to Teach. New York: Mc-Graw Hill

Bentley, Selassie, \& Shegunshi.2012. Design and Evaluation of Student-Focused eLearning.https://www.researchgate.net/publication/267262478

Bouchaib, B., Ahmadou, B., \& Abdelkader, S. (2018). High School Students' Attributions of success in English Language Learning. International Journal of Instruction, 11(2), 89102. https://doi.org/10.12973/iji.2018.1127a 
Chun, D.,Kern, R., \& Smith, B. (2016). Technology in Language Use, Language Teaching, and Language Learning. The Modern Language Journal, 100,64-80.

Efriana, L. (2021). Problems of Online Learning during COVID-19 Pandemic in EFL Classroom $\begin{array}{llll}\text { and the } & \text { Solution. } & \text { 38-47 }\end{array}$ https://jurnal.stkipmb.acid/index.php/jelita/article/view/74

Fauzi, R. Z., \& Asri, Y. (2020). Barriers and Solutions in Online Learning during the COVID-19 Pandemic, Indonesian Language Education Students at Riau Islamic University. Proceedings of the Ninth International Conference on Language and Arts (ICLA 2020), 539, 14-18. https://dx.doi.org/10.2991/assehr.k.210325.003

.Ferry, F, Grifoni, P, \& Guzzo, T. (2020). Online Learning and Emergency Remote Teaching; Opportunities and Challenge in Emergency Situation. Societies, 10(4), 86. http://doi.org/10.3390/soc10040086

Gay , L.R, Geoffrey E.Mills and Peter W. Airasian.2012. Educational Research : Competencies for Analysis and Applications. New Jersey : Pearson Educational, Inc.

Genç, G. (2016). Attributions to success and failure in English language learning: The effects of gender, age and perceived success. European Journal of Education Studies, 2(12), 25-43.

Gray, R. (2005). Attribution theory and second language learning: Results and implications. CELEA Journal, 28 (5), 13-17.

Gobel et.al.2013. Attribution to Success and Failure in English Language Learning: A Comparative Study of Urban and Rural Undergraduates in Malaysia.http://dx.doi.org/10.5539/ass.v9n2p53.

Haughey, M. and Anderson, T. 1998. Networking Learning: The Pedagogy of the Internet. Montreal: Cheneliere/ McGraw-Hill.

Hsieh, P. H. (2004). How college students explain their grades in a foreign language course: The interrelationship of attributions, self-Efficacy, language learning beliefs, and achievement. (Unpublished doctoral dissertation). University of Texas, Austin.

Khalil, Z. M. (2018). EFL Students' Perception towards Using Google Docs and Google Classroom as Online Collaborative Tools in Learning Grammar. Applied Linguistics Research Journal, 2(2), 33-48. https://doi.org/10.14744/alrj.2018.1488086

Lei, C. (2009). On the causal attribution of academic achievement in college students. Asian Social Science, 5, 87-96.

Mamluah ,S.K, \& Maulidi, A.(2021). Pembelajaran Jarak Jauh (PJJ) di Masa Pandemi Covid-19 di Sekolah Dasar. Jurnal Basicedu, 5(2). http://doi.org/10.31004/basicedu.v5i2.800

Mali Yustinus C.G.2014. Students' Attribution on their English Speaking Enhancement. http://dx.doi.org/10.17509/ijal.v4i2.681.

Mkumbo \& Amani 2012. Perceived University Students' Attribution of their Academic Success and Failure. http://dx.doi.org/10.5539/ass.v8n7p247. 
Richards, Jack C and Schmidt Richard.2002. Longman Dictionary of Language Teaching \& Applied Linguistics.London : United Kingdom

Schunk, Dale H, Pintrich, Paul R, and Meece , Judith L.2008. Motivation in Education Theory, Research, and Applications. New Jersey: Pearson Education ,Inc.

Schunk.2012. Learning Theories. An Educational Perspective . sixth edition. NewJersey: Pearson.

Thang Siew .M.2011.Students' attribution for Success and Failure in the Learning of English as a Second Language : A Comparison of undergraduates from Six Public Universities in Malaysia.http://www.pertanika2.upm.edu.my/Pertanika.

Weiner,B.(1985).An Attributional Theory of Achievement Motivation and Emotion.PsychologicalReview,92(4),548573.http://dx.doi.org/10.1037/003 3295X.92.4.548.

Widayanti, N. K.A., \& Suarnajaya, I.W. (2021). Students' Challenges in Learning English Online Class. Jurnal Pendidikan Bahasa Inggris Undiksha.9(1). 77-84. http://dx.doi.org/10.23887/ jpbi.v9i13446 